\title{
An Investigation and Evaluation of the Impact of the Integrated Language Skills Approach on English Departments EFL Students Speaking Skill in UOD
}

\author{
${ }^{1}$ Sabrin A. Ramadhan, ${ }^{2}$ Asma' A. Hussein \\ ${ }^{1,2}$ English Department, College of Languages, University of Duhok, Duhok- Kurdistan Region of Iraq
}

\begin{abstract}
Depending on the channel of communication, people use a variety of skills; particularly, listening and speaking. People often see the need to listen, understand and speak to one another in order to communicate successfully. For this reason, English learners are in need of learning the speaking skill effectively to be able to communicate successfully in real-life English situations. The study adopts theoretical and practical approaches to investigating and evaluating the impact of Listening and Speaking classes on the speaking skill of the students at the English Departments of the College of Languages and the College of Basic Education at the University of Duhok. The paper deals with teaching speaking skill and offers some activities on the speaking skill in the light of communicative language teaching (CLT) to assist the learners in communicating more efficiently in everyday English. The study adopts a mixed methods approach to evaluate the learners' attitudes towards their speaking skill by constructing a questionnaire for the students, and interviewing them. The study concludes that the integration of the listening and speaking skills helps to improve the students' speaking skill.
\end{abstract}

Keywords: CLT, Integrated language skills, speaking skill.

\section{Introduction}

Due to globalization, there is a growing need to communicate with other peoples from around the world using English especially as a "lingua franca" (Sewell ,2013). Normally, people in real life situations use more than one language skill to communicate with one another. The language used is spontaneous, in other words, it is full of reductions and other aspects of connected speech. But in a language learning setting the picture can be different; since the language to which the learners are exposed in their speaking classrooms is, to a certain extent, different from that used in the daily conducted by native speakers. The language learners often encounter problems with the spontanoues spoken form and they may feel excluded in situations where native speakers are involved (Cauldwell, 2014: 40-44). Therefore, educational planners are now more concerned with developing students' abilities to communicate more effectively with native speakers of

other languages in general and of English in particular .Consequently, the integration of language skills has come into existence in the form of listening and speaking, reading and writing wheraby the language used approximates the language used in real-life situations (Littlewood, 2013: 1). Thus, it has become a necessity to investigate and evaluate the teaching of listening and speaking skills in integration at English Departments at UOD(University of Duhok) and the influence of this approach on the students' speaking skill.

\section{Aims of the Study}

This study aims at investigating and evaluating the influence of integrating the teaching of listening with speaking on the $2^{\text {nd }}$ year students' speaking skill at English Departments at UOD. The English Departments of the College of languages and the College of Basic Education have adopted the integrated-skills approach 
in their $1^{\text {st }}$ and $2^{\text {nd }}$ years' since 2013, respectively. Therefore, the study is confined to these two departments in particular.

\section{Question of the study}

The study raises and seeks to find answer to the question which reads as " does the integration of the listening and speaking skills help to improve the learners' speaking ability?".

\section{Hypothesis of the study}

The study hypothesizes that the integration of the listening and speaking skills helps to improve the learners' speaking ability.

\section{Significance of the Study}

The findings of this study will be significant for shedding light on, and giving insight, as well as a voice to the students' communicative needs; consequently, it can benefit teachers, education planners, and syllabus designers regarding the teaching of the listening and speaking skills in integration. The significance of the study also lies in offering the teachers a variety of speaking activities to implement in their classrooms.

\section{Model of the Study}

The study adopts Communicative Language Teaching (CLT) approach in which speaking skill plays an active role in language classrooms. Therefore, this modern approach mainly concentrates on teaching the authentic or the real-life language of native speakers (Rost, 2011: 146); it is for this reason that our study adopts the CLT for the speaking skill.

\section{Literature Review}

Honeyfield (1988: 1) defines skills' integration as the combination of more than one skill such as listening and speaking, reading and writing. Richards \& Schmidt (2002: 262) define skills integration as "the teaching of the language skills of reading, writing, listening, and speaking, in conjunction with each other, as when a lesson involves activities that relate listening and speaking to reading and writing".

Traditionally English language teachers concentrated on teaching the four language skills (listening, speaking, reading and writing) in segregation (Kecira \& Shllaku, 2014: 1-3). But Widdowson (1978) believed that the central function of languages is to connect people with one another in social contexts where they use more than one skill (As cited in Kecira \& Shllaku, ibid). Accordingly, for the sake of becoming a good language user learner need to develop their productive skill (speaking and writing) as well as their receptive skills (listening and reading) in integration.

According to Harmer (2000: 52), people in real- life situations usually use more than one skill to communicate. Similarly, in a classroom setting, students listen to a lecture and take notes from the lecture (i.e. writing) and then they explain them to each other (i.e. speaking) which reflects a whole communication process. It is quite difficult for people to comment on and engage in a conversation without listening to the hearers (Harmer, ibid). Therefore, teaching the four skills in isolation is of less value because normally skills cooccur.

Hinkle (2010: 10-11) distinguishes between "simple integrated skills" and "complex integration of the skills". The former refers to the integration of listening and speaking skills together or the integration of reading and writing skills in language classrooms; whereas the latter refers to the combination of more than two language skills in language classrooms. Typical English language classes in most parts of the world apply receptive and productive skills of their learners, so that in the speaking class, listening materials are used as models for speaking, and in writing classes; reading materials are used as models for writing. Additionally, some class activities may involve listening and reading materials to improve the learners' speaking and writing 
skills.

In this regard, Hinkle (2006: 112) explains that the integration of the listening skill with the speaking skill is one of the currently accepted views on the successful learning and teaching of English.

Jing (2006) concluded that the integration of the skills in EFL classes helps the students to concentrate more on creating realistic situations where English is in use naturally and spontaneously. Consequently, this will motivate the learners to be more active and enthusiastic about their English language learning.

Sánchez (2000: 35) clarified that the integrated-skills approach (ISA) is critical to the teaching and learning of speaking as it provides learners with enough motivation to communicate in purposeful situations in classroom activities.

The integrated approach conforms to the CLT which gives enormous attention to improving learners' communicative skills and helps in creating opportunities for language learners' to be engaged in various activities in class, as well as to practice their English in meaningful communication (Hinkle, 2006: 113). Therefore, the integration of the skills is a typical norm in classrooms which employ CLT. Hinkle (ibid: 113) states that in "an age of globalization, pragmatic objectives of language learning place an increased value on integrated and dynamic multiskill instructional models with a focus on meaningful communication and the development of learners' communicative competence".

The integration of the skills helps learners to be exposed to natural English in meaningful situations (See Oxford, 2001, and Sbai, 2016).

\subsection{The Impact of ISA on the Learners' Communicative}

\section{Skills: Previous Studies}

In recent years, a number of studies have been conducted to investigate the effect of the integration of the listening and speaking skills on learners' communication ability. Tavil (2010) conducted a study on 180 pre-intermediate level students from the preparatory classes of Hacettepe University, in Turkey in order to prove the hypothesis that teaching listening and speaking skills in integration facilitates the learners' speaking skills. The results of Tavil's experiment proved the hypothesis to be right.

Moreover, the study concluded that for learners to be able to communicate with other speakers of English, it is essential that they learn to listen for the message and main ideas rather than for the sake of the language itself, which is also a claim made byRichards \& Rodgers (2001: 173).

A similar study was carried out by Floriasti (2013) to investigate the impact of the skills integration on learners' communicative skills. The findings of the study indicated that there was a gradual improvement in the participants' performance despite the fact that the study did not give any clear discussion of the participants' level of English proficiency (beginner, intermediate, advanced) which Brown (2001, p. 86) stressed to be very important for teachers to take into account before selecting and designing activities plus the materials for their learners. The findings of these studies present additional evidence that supports the hypothesis of our study.

In 2015, Tajan, Sadeghi, and Rahmany conducted a study on 30 female students from Safir English Institute in Lahijan, Iran to explore the impact of the integration of listening activities on the learners' speaking accuracy. The findings of the study demonstrated that the integration of listening activities in classroom enhanced the learners' speaking skills. The authors concluded that the integration of the listening and speaking skills assisted in motivating intermediate level learners, or even lower levels to learn English more successfully. 
The role of motivation in language learning has been stressed by Harmer (2007: 20) who defines it as the desire to accomplish an aim. Harmer further discusses the teachers' main goal to be keeping the learners motivated through keeping them engaged in, and curious about the class activities.

Whilst the findings of previous research are in favor of the hypothesis of our research study, the researchers nonetheless fail to further account for the learners' own interests and opinions about what they are interested in learning before conducting their tests or tasks. According to Jones (2007: 1-2), in this regard, the student is the center of teaching methods; students' interests, likes, dislikes and past experiences are taken into consideration by the teacher when planning a lesson. Jones continues that learners are active participants in the learning process and can construct their own knowledge, beliefs and concepts from their experiences as they go through various situations in their lives and class with their classmates; they can also bring their own ideas about how to learn and what to learn, which in a way or another gives room for the learner to take charge of their own learning and be somehow autonomous.

Despite the considerable body of literature on the integrated approach to the four language skills in general, and on listening and speaking skills in particular, the literature suggests that there is a need for additional practical work in language classrooms where the integration of listening and speaking is practiced in order to discover the possible difficulties that teachers and learners may face while dealing with this integration. Therefore, and in an attempt to give the learners' a clearer voice and to further extend and contribute to the literature on the integration of listening and speaking skills, our study adopts certain methodology tools such as distributing questionnaire to the language learners, and interviewing them to discover their attitudes towards the Listening and Speaking classes.

\subsection{Teaching the Speaking Skill in the Light of CLT}

For the implementation of CLT in language classroom activities, some features need to be available. Johnson and Johnson (1998) (as cited in Richards \& Rodgers, 2001: 173) define five features of the present application of CLT, namely:

- Appropriateness: Language use needs to be appropriate to the situation in which it is used based on the participants' roles, setting, and the purpose of communication. In other words, the learners need to be able to use formal versus informal styles of speaking.

- Message focus: The learners need to be capable of creating and comprehending messages in CLT activities.

- Psycholinguistic processing: This refers to CLT activities which involve learners in the use of the cognitive processes in second language acquisition such as identifying different sounds of the target language and combining them to make meaningful words or sentences, etc. in their speaking.

- Risk taking: Teachers are expected to support and encourage the learners to make predictions and learn from their mistakes.

- Free practice: CLT calls for the use of "holistic practice" that is the practice of a variety of the skills in integration, not just the individual skills one at a time such as listening and speaking skills.

Teaching the speaking skill in the light of CLT can be challenging for teachers to use in their language classrooms, especially in large classes, limited resources, the teachers' own beliefs about teaching, etc. Nevertheless, adopting CLT in teaching the speaking skill can also be of great help and benefit to the language learners. 


\subsection{Speaking Activities in the Light of CLT}

There is unlimited number of CLT activities that the teachers can use in their language classrooms. According to (Richards \& Rodgers, 2001: 170), since the activities used in CLT classrooms can be various; it is hard to give a precise description of what they look like, because CLT principles can be applied to any skill and at any level of the language. It is significant that teachers make certain that their students understand the instructions for the activity, prior to starting the activity. Harmer (2007: 129) suggests that teachers can get their students to demonstrate how an activity works in front of the whole class, or they can ask their students such questions: Do you have a good idea of what you are going to do next? Can anyone explain to us what we are going to do? It is also very important that teachers always establish a time limit for any class activity before the learners begin to perform it which is given within the instruction of the activity as well (Jones, 2007: 21).

Richards and Rodgers (2001:197-199) suggest some communicative activities for the learners each with a certain goal or rationale. Some activities, promote a sense of cooperation among the learners, which leads to building and improving their social skills, such as the Jigsaw activity; whereas other activities, such as: 'Thinkpair share' and 'Solve-pair share' improve the learners' critical thinking as well as generally promote communication among the learners (See Richards and Rodgers, 2001; Dixon, 2016).

\section{Methodology}

The study adopted a mixed approach which is qualitative and quantitative and in the light of CLT the data were analyzed. The qualitative part includes interviews with $2^{\text {nd }}$ year students of Listening and Speaking classes of English Departments at the College of Languages and the College of Basic Education. The quantitative part includes the construction of Likert scale in which the questionnaire will look into students' views on their listening and speaking classes at both colleges. The participants of the questionnaire mainly involved $2^{\text {nd }}$ year students because they had already studied the skills of speaking and listening in integration in their first year of college. The quantitative data of the questionnaire were analyzed by SPSS version 22 .

\subsection{Data Collection}

The sample of the participants of the study was a purposive sample and it consisted of 150 students. The sample constitutes the interviews with the students; the data were elicited from 32 students from the second year students at the English departments at the College of Languages and the College of Basic Education from November 11 to 14, 2018. However, 6 other participants were interviewed using focus group discussion at the College of Basic Education. Three other participants from the College of Languages agreed to be interviewed in a focus group discussion. The main aim for using focus group discussion in this study was to save time and effort of the researcher and the participants.

The interviews were conducted between November 11 and 14,2018 . The duration of each interview was around 5 minutes. The participants were asked open questions and were allowed time to think about the questions in order to give free and detailed answers. The interviews were audio-recorded, with permission of the participants, and then they were transcribed verbatim by the researcher to be analyzed.

Focus group discussion is usually synonymous with "group interviews" where a group of around 8-12 participants (interviewees) of similar backgrounds are gathered in a group to discuss a specific topic of interest. A focus group discussion is led by an interviewer (Baral, et al., 2016: 1). 
The focus group discussion was held with 6 participants, at the College of Basic Education, in the Phonetics Lab, at the English department. The group discussion was held for approximately 11minutes on November 11, 2018. Another focus group discussion took place with 3 participants from the College of Languages, in the college library and lasted for 6 minutes. The discussion was conducted on November 14, 2018.

The questionnaire was distributed to 51 participants from the College of Basic Education and to 50 participants from the College of Languages.

\subsection{Pilot Study}

Following Gass and Macky (2005) and Simon (2011) a pilot study was carried out on a number of students from the $2^{\text {nd }}$ year at the College of Languages and the College of Basic Education to

- Ensure more validity and reliability of the methodology of the study.

- Ensure that the practical items are understandable.

- Discover any weaknesses or problems in the practical items.

- See if the items need further revision and modification.

Twenty $2^{\text {nd }}$ year students were chosen from the two English Departments to participate in the pilot study to test the questionnaire, and interviews questions for the students. Tables (1) (2) and below summarise the details of the pilot study.

Table 1

Participants of the pilot study for the questionnaire

\begin{tabular}{llllll}
\hline \hline Level & \multicolumn{2}{l}{ Gender } & Total & College \\
\cline { 2 - 4 } & Male & Female & & \\
\hline $2^{\text {nd }}$ year & 5 & 5 & 10 & & College of Languages \\
$2^{\text {nd }}$ year & 3 & 7 & 10 & $\begin{array}{l}\text { College of Basic } \\
\text { Education }\end{array}$ \\
Total & 8 & 12 & 20 & & \\
\hline \hline
\end{tabular}

Table 2

Participants of the pilot study for interviewing the students

\begin{tabular}{|c|c|c|c|}
\hline \multirow[t]{2}{*}{ Level } & Gender & Total & \multirow[t]{2}{*}{ College } \\
\hline & Male & Female & \\
\hline
\end{tabular}

\begin{tabular}{lllll}
$2^{\text {nd }}$ year & 1 & 1 & 2 & $\begin{array}{l}\text { College of Languages } \\
\text { 2nd }\end{array}$ \\
Tear & 1 & 1 & 2 & $\begin{array}{l}\text { College of Basic } \\
\text { Education }\end{array}$ \\
\hline
\end{tabular}

\subsection{The Validity}

In order to ensure the validity of the practical part, the items of the questionnaire, and interview question were presented to a jury of specialized linguists and applied linguists before carrying out the experimental part. The notes, comments, and remarks of the jury, which contributed to the validity of the experiment, were faithfully taken into consideration by the researcher.

\subsection{The Reliability}

The reliability of the questionnaire items was tested using SPSS (Statistical Package for the Social Sciences). The Cronbach's Alpha obtained for the questionnaire was $72 \%$, which proves that the instrument of the study here (the questionnaire) has good reliability (See Table 3).

Table 3

The reliability statistics of the questionnaire items.

\begin{tabular}{ll}
\hline \hline Cronbach's Alpha & N of Items \\
\hline 728 & 8 \\
\hline \hline
\end{tabular}

To ensure the credibility of the answers, one question among the questionnaire items was repeated twice deliberately in order to see whether or not the students were actually thinking about the questions and their answers.

For ethical considerations, all the interviewees gave their explicit consent to being interviewed and to being audio-recorded through a signed Consent form. Three participants however, did not wish to be audiorecorded; therefore, the researcher took notes of their comments instead. The participants were given information about the nature of the research study and the use that would be made of the data they provided.

\section{Results}


9.1 Analysis of $2^{\text {nd }}$ Year Students' Interview and Focus Group Discussion Responses

The students were asked the following six open-ended questions that aimed to elicit their attitudes towards their Listening and Speaking classes. The data were analyzed using Content Analysis approach (CA), the responses were organized in terms of the themes provided by the students' responses to the open-ended questions of the interviews.

Question 1. Is your Listening and Speaking class interesting? Why?

In response to this question, all the 32 participants from the individual interviews and the 9 participants from the focus group discussion at both colleges asserted that their class is interesting. The responses centered around the teacher and the activities that the teacher implemented in the class which make their Listening and Speaking class interesting. Below are some samples of the responses:

- Eleven participants stated that their listening and speaking class is interesting because their teacher is very good, and she helps them to improve their listening and speaking skills: "yes, it is interesting because our teacher does her best to teach us how to speak and listen".

- Eleven participants attributed the reason to the various activities that they do in the class such as debates, and group discussions. An interesting comment was made by a participant who stated "Of course, yes, because it is my affection" . In a similar vein, the nine participants, from the focus group discussion at both colleges commented that their listening and speaking class is interesting, because they do different kinds of activities in the class.

- Five participants remarked that the different topics they discuss in the class are the main reason which make their listening and speaking class interesting.
- Five of the participants said that their listening and speaking class is interesting due to the fact that these two skills are the most important skills in the English language. One of them continued " It is interesting because we need listening and speaking class in our lives" .The responses of the latter five participants show that the students are aware of the significance of the listening and speaking skills in real-life situations.

Question 2. Do you enjoy your Listening and Speaking class? Why?

Out of 41 participants from the individual interviews and group interviews, only 38 stated that they enjoy studying both the listening and speaking skills. Below are some samples of the responses:

- Two participants said that they enjoy their class as it improves their English language.

- Six participants commented that they enjoy the class because their teacher and their colleagues are nice and good. The answer of the latter four participants brings forth the undeniable impact of a friendly classroom atmosphere in making learning more enjoyable to the students.

- Twenty-two participants said that they enjoy the class, because they talk about different topics and cultures of other peoples and because they work in groups.

- Two participants commented that her listening and speaking class is enjoyable because "as groups we challenge each other" (Interview, November 13, 2018). The participants' comment indicates the importance of group work in instigating a sense of competition among the students which can have a positive impact on the students' pursuit to become better language learners (see, e.g. Taqi \& Al-Nouh: 2014).

- Three participants from the group discussion at the 
College of Languages said that they enjoy speaking more than listening because they find the listening boring (Group interview, November 14, 2018). The six participants from the group discussion at the College of Basic Education, on the other hand, commented that they enjoy studying both the listening and speaking skills because of the group work (Group interview, November 11, 2018).

Question 3. What difficulties do you face in your Listening and Speaking class?

This question evoked different responses by the students, below are some samples of their responses:

- Eight participants stated that listening is difficult because they do not have vast knowledge of vocabulary, which is a major difficulty in their listening skill.

- Two participants remarked that they face difficulty with listening to British accent.

- Twelve participants commented that sometimes listening is difficult because the speakers speak too fast. One of them stated that "Listening is a bit difficult because speakers speak too fast but I am trying to practise every day to be like them". In other words, the student is attempting to overcome the difficulty and take responsibility for his learning by practising his listening skill regularly.

- 4.Two other participants stated that speaking is a challenge for them because it is not their native language.

- Three participants remarked that sometimes speaking in front of everyone in the classroom is difficult because they feel shy.

- One participant stated that pronunciation of some words is difficult for him.

- Four Participants, on the other hand, commented that nothing is difficult for them.

- 8.Three participants from the focus group discussion at the College of Languages were of the opinion that "Group work is hard because we are not close to each other" (Group interview, November 14, 2018).The focus group's comment points out to the poor communication among the members of one group and its negative impact on the students' performance as a whole, as it often leads to poor performance in the classroom (see, e.g. Taqi \& AlNouh :2014). The other focus group discussion at the College of Basic Education, remarked that the audios the teacher plays in the class are hard to follow, because of the fast speech of native speakers (Group interview, November 11, 2018).

Question 4. Does your Listening and Speaking class help you to improve your speaking skill? Why.

The 41 participants emphasized that their listening and speaking classes are improving their speaking skill and they provided different reasons for their answers as follows:

- Seventeen participants attributed the reason to the sufficient practice of listening and speaking skills in the classroom.

- For seven participants, their speaking skill was improving because the materials used are good and help them to communicate with native speakers.

- 3.Another participant gave an interesting reason "because it motivates us to practice our language" (Interview, November 13, 2018)

- 4.Three participants commented that their listening and speaking class is improving their speaking because of the different activities they do and the various topics they discuss in the classroom.

- 5. Four participants did not provide any clear reasons for their answers.

- 6.The 3 participants from the group discussion at the College of Languages sounded the opinion that "it improves speaking, listening too but not as much as 
speaking" (Group interview, November 14, 2018).

Whereas, the 6 participants from the group discussion at the College of Basic Education, commented that their speaking skill is improving because they are not allowed to speak their native language (Kurdish) inside class and this helps them to practice their English language more (Group interview, November 11, 2018).

Question 5. If you could meet a native speaker of English in person, would you be able to have a conversation with her/him?

- Three participants answered that they are afraid and shy to speak to native speakers of English.

- Two other participants said "maybe".

- Two of the participants stated "yes, although my language is not fluent yet but I will do my best" (Interview, November 13, 2018). The latter comment reflects the importance of self-confidence as a factor to overcome shyness in communicating with native English speakers despite the imperfection of the language.

- Twelve participants commented that they can communicate with native speakers.

- Thirteen participants remarked that they can speak to native speakers of English because they already communicate with native speakers on social media such as Facebook using Messenger application. This points to the students' increasing awareness of the opportunities provided by the social media as a means of exposure to real English language use; otherwise the students may have little chance to meet native speakers of English in their part of the world.

- Two participants from the group discussion at the College of Languages said that they can't speak to native speakers of English because "they speak too fast, we can't catch up" (Group interview,
November 14, 2018). The other participant commented that she can. The six participants from the focus group discussion at the College of Basic Education, stated that they can communicate with native speakers because they already interact with them on social media (Group interview, November 11, 2018).

Question 6. What do you suggest for your teacher to add to your Listening and Speaking class?

- Six participants emphasized that their teachers are good and do not need to add anything to their Listening and Speaking classes.

- Twenty-five participants suggested that they need more chances to give presentations, to listen more, as well as to have more enjoyable and involving activities like debates.

- One participant remarked that she needs the audio recorder to be played more than twice.

- Seven participants from the group discussion at the both colleges commented that they suggest more speaking time and two of the participants made no suggestions.

\subsection{Analysis of the Questionnaire}

The questionnaire items were adapted from Richards (2001) and they were composed of eight items on the speaking skill. The questionnaires were distributed on November 18 and 19, 2018. The questionnaire part was analyzed using SPSS version 22.

The first step in the statistical analysis of this research study was testing the normality of the questionnaire items using SPSS (22). The normality test was conducted to determine whether the data is normally distributed, well-modelled, and that the results of the test are reliable, valid as well as accurate (see e.g. Das \& Imon, 2016). In a more technical sense, normality is achieved when the "sampling distribution of the mean is normal or that the distribution of means across samples is 
normal" (Mordkoff, 2016:1-2).

The results of the normality test of the questionnaire prove the data to be normally distributed as shown in Table (4) below:

Table 4

Results of the Tests of Normality

\begin{tabular}{lllllll}
\hline \hline & \multicolumn{3}{c}{ KolmogorovSmirnov $^{\text {a }}$} & \multicolumn{3}{c}{ Shapiro-Wilk } \\
\cline { 2 - 7 } & Statistic & Df & Sig. & Statistic & df & Sig. \\
\hline Speaking & 0.060 & 101 & $0.200^{*}$ & 0.990 & 101 & 0.692 \\
\hline \hline
\end{tabular}

For the data to be in normal distribution the results of the significance (sig). should be higher than 0.05 (for further details on Normal distribution, see Mordkoff, 2016). In the light of the 'Shapiro-Wilk' results, the Sig shows 0.692 for speaking which indicates that the data are normally distributed for our study.

The bell-curve shaped histogram in Fig .1 below further asserts the data to be in normal distribution (For thorough details, see Das \& Imon, 2016)

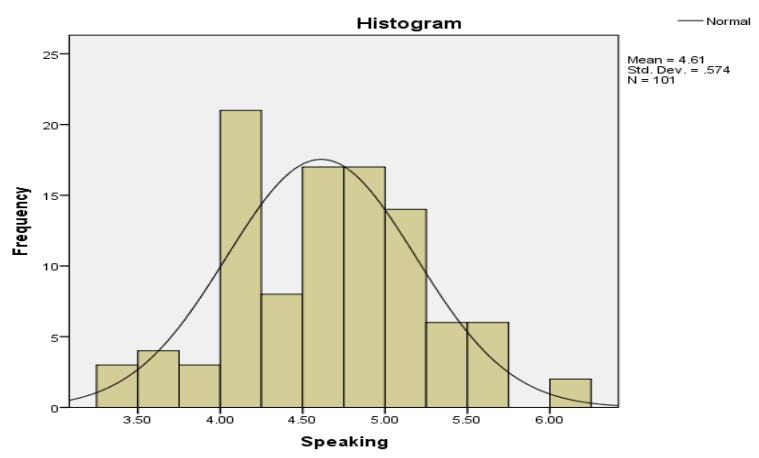

Figure 1. The Histogram of the Results for Speaking

Table (5) below shows the calculation of the mean for each option item of the questionnaire that the participants chose for their answers.

Table 5

Five Point Likert Scale of the Questionnaire Design

\begin{tabular}{llll}
\hline Likert scale & Interval & Difference & Description \\
\hline 1 & $100-1.79$ & 0.79 & Always \\
2 & $1.80-2.59$ & 0.79 & Often \\
3 & $2.60-3.39$ & 0.79 & Sometimes \\
4 & $3.40-4.19$ & 0.79 & Rarely \\
5 & $4.20-5.00$ & 0.80 & Never \\
\hline \hline
\end{tabular}

\subsubsection{Analysis of the Questionnaire Items on Speaking}

The Figures below show the responses of the 2nd year English department students from the two colleges to question items $(2,3,4,5,6,8,9$, and 17) on speaking along with the percentages, obtained for each option.

Figure (2) shows that $29 \%$ of the respondents sometimes face difficulty with speaking, and $27 \%$ often do. The mean obtained from this question was 3.03 which indicates that the respondents sometimes face difficulty with the speaking skill.

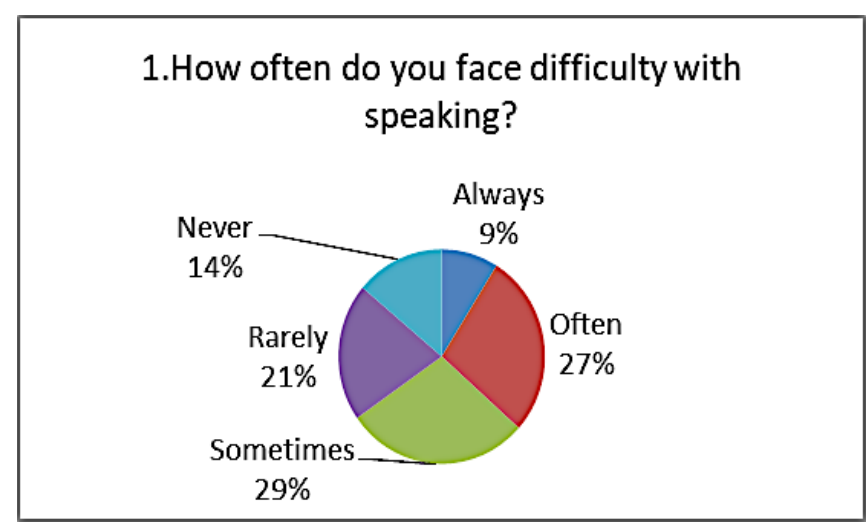

Figure 2. Students responses to question (n.1) in percentages

Figure (3) reveals that $30 \%$ of the respondents sometimes face difficulty participating in large discussions or in debates. An insignificant difference between the percentages for "often" and "rarely" having difficulty participating in discussion and debates was obtained, at $23 \%$ and $22 \%$ respectively. The mean for this question is 3.05 which suggests that the students sometimes have difficulty participating in large group discussions and debates.

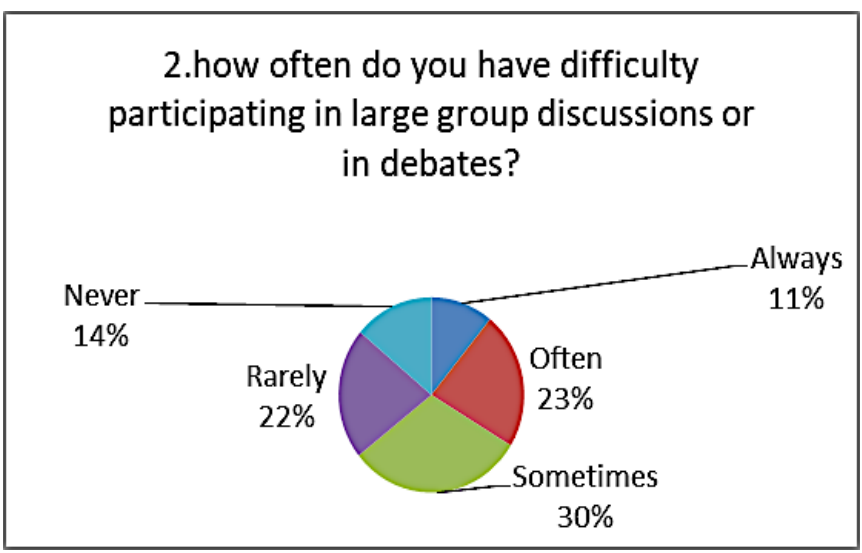


Figure 3. Students responses to question (n.2) in percentages

The pie chart in Figure 4 below, shows that $52 \%$ of the students have interaction with the native speakers of English, but they sometimes struggle with communicating with them. $28 \%$ of the respondents often struggle in communicating with the native speakers. The mean was 2.76, which suggests that the students sometimes struggle with interaction with native speakers of English.

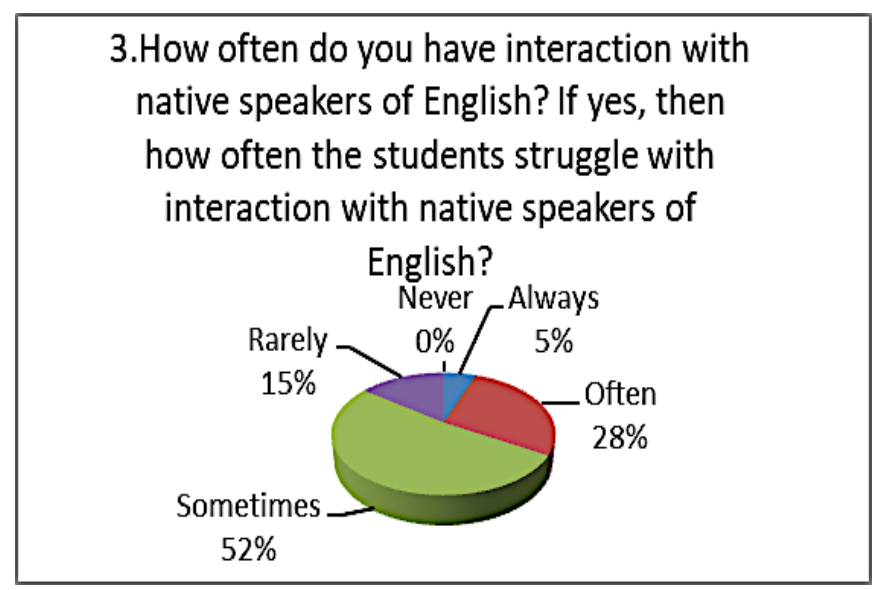

Figure 4. Students responses to question (n.3) in percentages The findings in Figure (5) shows that $35 \%$ of the students sometimes have difficulty giving oral presentations but $24 \%$ of them rarely do. The mean for this question was 3.17 which means that the students sometimes have trouble giving oral presentations.

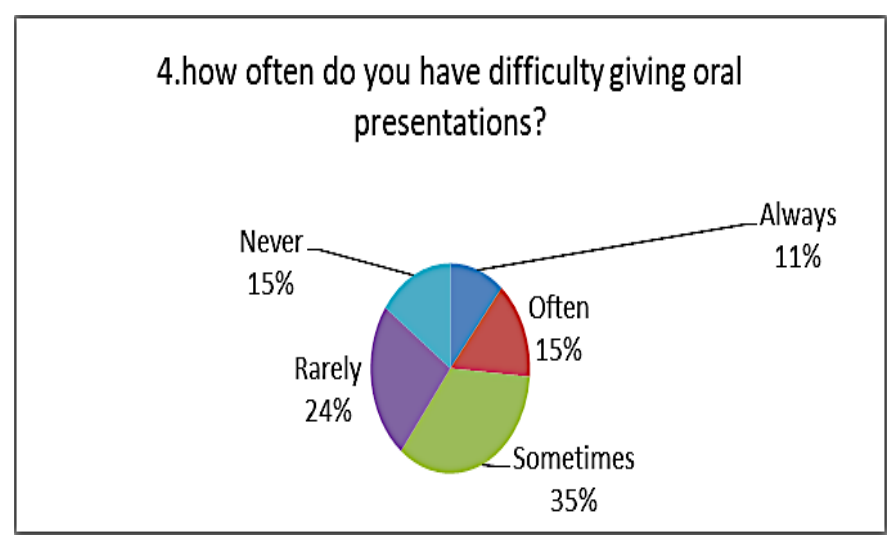

Figure 5. Students responses to question (n.4) in percentages
The results of question (5) on how often the students have trouble saying what they want to say quickly enough, reveal that $39 \%$ of the students sometimes have trouble speaking quickly enough. Additionally, 21\% often do. As shown in Table (5), the mean for this question was 2.82 which implies that the students sometimes have difficulty saying what they want to say fast enough.

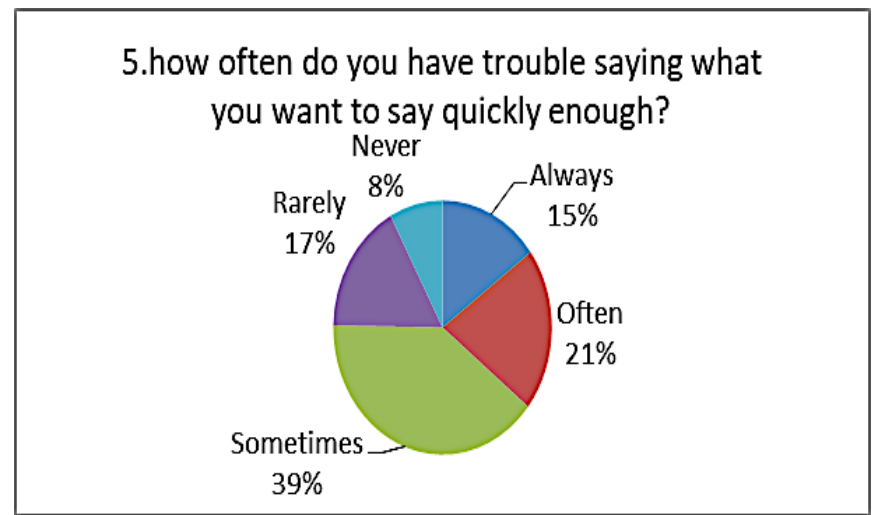

Figure (6) Students responses to question (n.5) in percentages

The analysis of the Figure (7) reveals that $28 \%$ of the students often worry about making mistakes in speaking, whereas $24 \%$ of them sometimes do. The mean for this question is 2.87 which means that the students sometimes worry about making mistakes in the speaking skill.

\section{6. on how often the students worry about making a mistake in speaking?}

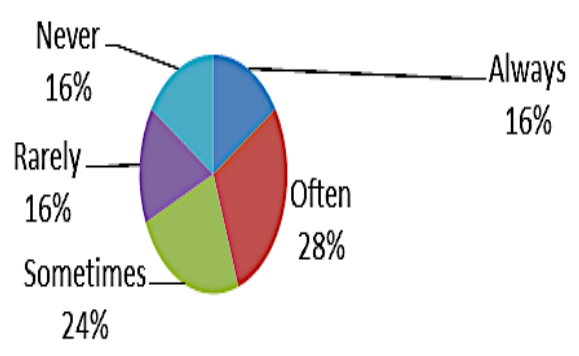

Figure 7. Students responses to question (n.6) in percentages

The findings for question (7) on how often the students have difficulty with their pronunciation of words, show that $37 \%$ of the students sometimes encounter difficulty 
with the pronunciation of words; whereas, $26 \%$ of them rarely do. The mean for this question was 3.12 which indicates that the students sometimes have difficulty with their pronunciation of words.

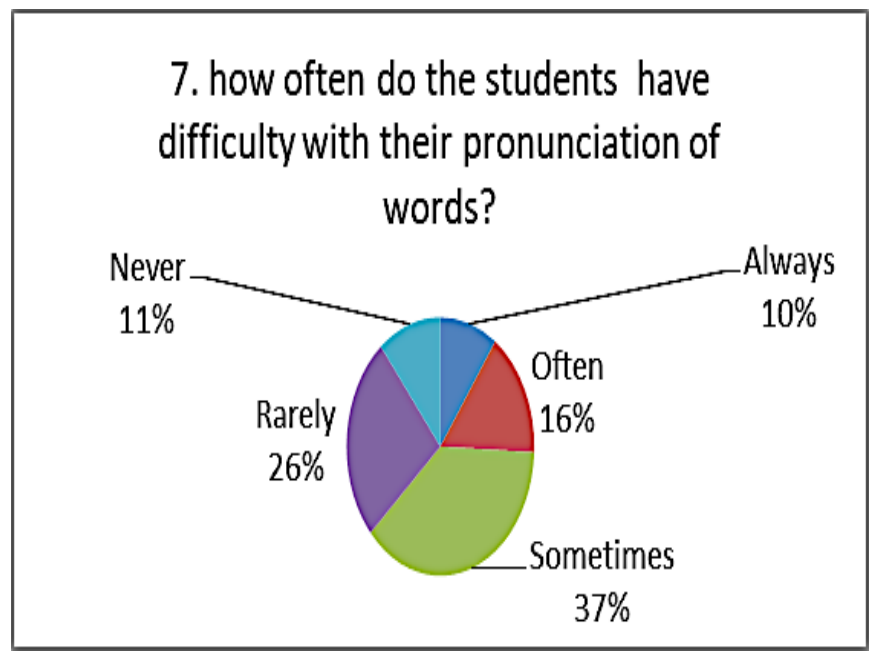

Figure (8) Students responses to question (n.7) in percentages

Question (8) asks how often the students practice the speaking skill outside the classroom. As Figure (9) illustrates $25 \%$ of the students always practice their speaking skill outside the classroom; whereas, $29 \%$ of them sometimes do. As shown in Table (5) the mean for this question is 2.57 , which suggests that the students sometimes practice their speaking skill outside the classroom settings.

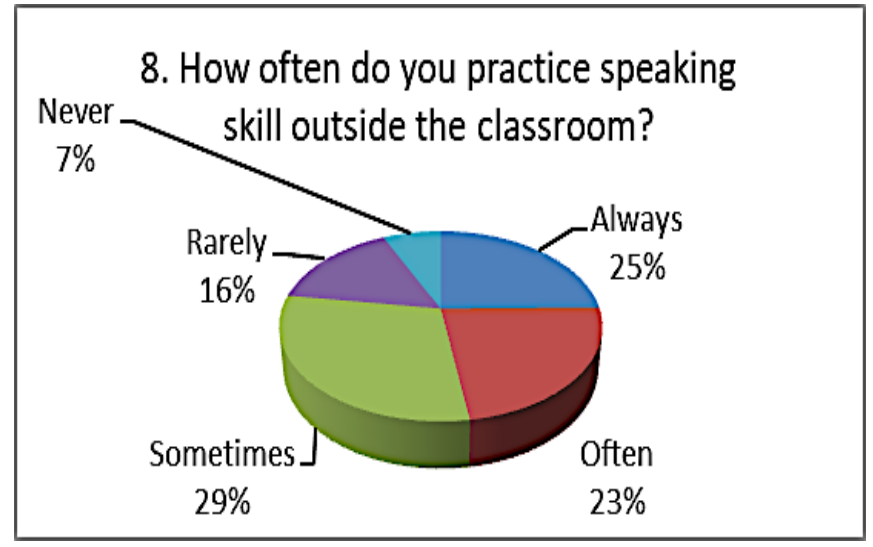

Figure (9) Students responses to question (n.8) in percentages

\section{Discussion of the Results}

The findings of the qualitative and quantitative analysis of the items which address our main research hypothesis, namely "the integration of listening and speaking skills helps to improve learners' speaking ability" indicate that the students' speaking skill is improving because a number of models of the integrated-skills approach are being employed by the teachers in the classrooms, for instance, theme-based instruction (TBI), and task-based language teaching (TBLT) which are significant in meeting students' different interests and engaging them in everyday-life situations to speak English and learn it more effectively (see, e.g. Brown: 2001). The analysis has revealed the strong impact of social media on developing the students' speaking skills. A very good percentage of students (52\%) involved in actual interaction with native speakers of English through social media channels, which has a direct influence on their speaking skill.

The analysis has also revealed the role which psychological and/or personality factors play in impeding the students' speaking skill, such as introvertedness, or shyness to speak in front of an audience, whether a group of classmates, or native speakers.

In the Listening and Speaking classrooms, the teachers are trying to implement CLT in the best possible way as to ensure the improvement of their students' communicative skills via a variety of classroom activities (see, e.g. Harmer: 2007).

The qualitative analysis of the classrooms observations has revealed the students to be engaged and motivated to learn English in classrooms where listening and speaking skills are taught and learnt in integration. This gives support to Tajan's et al. (2015) and Tajan (2016) findings that the integration of the listening and speaking skills helps to increase the motivation for teaching and learning English more successfully.

The second-year students have positive attitudes towards their Listening and Speaking classes which suggests that the teachers are successful in their teaching 
of the listening and speaking skills. This conforms well to the results of studies by Tajan et al. (2015), and Tajan (2016) on the importance of a successful teaching of listening and speaking skills to students as a main contributor to the students' developing positive attitudes towards the language they are learning.

\section{Conclusions}

The study has arrived at the following conclusions:

- Teaching the listening and speaking skills in integration helps to better the students speaking skill. In other words, the hypothesis of the study proved to be right.

- The integration of the listening and speaking skills contributes to boosting the students' motivation to communicate and engage in the Listening and Speaking classes.

- The major difficulties faced by the students in their Listening and Speaking classes relate to the fast speech on the audios, as well as the students' selfconsciousness which makes them hesitant and uncomfortable to speak in front of the whole class.

\section{Pedagogical implications}

The main goal of CLT is to help language learners to communicate successfully in the target language and to cope with, and understand real-life English by native speakers. Therefore, teaching listening and speaking skills in integration and in a proper way by English teachers can assist the students in learning the target language more effectively. The present study suggested a variety of the speaking activities which English teachers can make good use of, in their classrooms in order to improve their learners' communication skills (for a through description see speaking activities in the light CLT Section). By virtue of being English department students, the students need to be exposed to more accents of the English language. Listening and Speaking classes are the best medium to meet this need.
The students need more exposure to real-life English situations where they can speak with native speakers of English as well as get more knowledge of vocabulary, pronunciation, stress, and intonation.

\section{Suggestions for Future Research}

Further research can be carried out on this research topic by:

- Investigating the impact of the Integrated-skills approach on improving the learners' pronunciation in terms of developing an intelligible accent while communicating with native speakers of English.

- Investigating the impact of the Integrated-skills approach on eliminating the feeling of shyness or self-consciousness that the learners have when speaking in front of their colleagues or other speakers of English.

- 3.Investigating the impact of Integrated-skills approach on the learners' listening and speaking skills, particularly, making a comparison between the Listening and Speaking classes of two colleges. Such as, the Listening and Speaking classes at the College of Languages and the College of Basic Education.

\section{References}

1. Brown, H. D. (2001). Teaching by principles: An interactive approach to language pedagogy $\left(2^{\text {nd }} \mathrm{ed}\right)$. White Plains, NY: Longman.

2. Baral, S. et al. (2016). Focus group discussion. A HERD Publication. Retrieved from https://www.herd.org.np/uploads/frontend/Publicatio ns/PublicationsAttachments1/1485497050Focus\%20Group\%20Discussion_0.pdf

3. Cauldwell, R. (2014). Listening and pronunciation need separate models of speech. In J.Levis\&S. McCrocklin (Eds). Proceedings of the $5^{\text {th }}$ Pronunciation in Second Language Learning and Teaching Conference (pp.40-44). Ames, IA: lowa State University

4. Das, R., K. \& Imon, R., H. (2016) A Brief Review of Tests for Normality: American Journal of Theoretical and Applied Statistics. 5(1):5-12.

5. Dixon,Sh. (2016). 100 TESOL activities for teachers: Practical ESL/EFL activities for the communicative classroom. Arizona State University. 
6. Floriasti, T., W. (2013). Improving speaking skills through the use of integrated listening and speaking material for student teachers. Yogyakarta State University.

7. Gass, S., \& Mackey, A. (2005). Second language research: Methodology and design. New Jersey: Lawrence Erlbaum.

8. Harmer,J. (2000). The practice of English language teaching. London: Longman Group UK limited, Longman House, Burnt Mill,Harlow.

9. Harmer, J. (2007). How to teach English (new edition). London: Pearson Education Limited.

10. Hinkel, E. (2006). Current Perspectives on Teaching the Four Skills. TESOL QUARTERLY,40(1),109-131.

11. Hinkel, E. (2010). Integrating the Four Skills: Current and Historical Perspective. The Oxford Handbook of Applied Linguistics. Oxford, England: Oxford University Press.

12. Honeyfield, J. (1988). Skills integration: What is it and do we need it? Guidelines: A Periodical for Classroom Language Teachers, (10),2; 25-33.

13. Jing,W.(2006). Integrating skills for teaching EFLActivity design for the communicative classroom. Sino-US English Teaching, 3(12), 1-5.

14. Jones, L. (2007). The student-centered classroom. New York, NY: Cambridge University Press.

15. Kecira,R. \&Shllaku,A.(2014).Skills segregation versus skills integration in ELT. Conference-Paper Proceedings,2308-0825.

16. Littlewood,W. (2013). Developing a Context-Sensitive Pedagogy for Communication- Oriented Language Teaching. Hong Kong Baptist University.

17. Mordkoff, T. (2016). The Assumption(s) of Normality. Retrieved from

18. http://www2.psychology.uiowa.edu/faculty/mordkoff /GradStats/part\%201/I.07\%20normal.pdf

19. Oxford,R.(2001). Integrated skills in ESL/EFL classroom. The Journal of TESOL France. 8, pp.5-12.

20. Richards , J.C. \& Rodgers,TH.S. (2001). Approaches and methods in language Teaching(2nd ed). UK: Cambridge University Press.

21. Richards, J. C. (2001).Curriculum Development in language teaching. UK: Cambridge University Press.

22. Richards,J,C. \&Schmidt, R. (2002). Longman Dictionary of language teaching and applied linguistics ( $3^{\text {rd }}$ ed). Pearson Educated Limited.

23. Rost, M. (2011). Teaching and researching listening (2 ${ }^{\text {nd }}$ ed). In Hall, R.,D. \& Candallin, N.,C. (eds). Applied linguistics in action. Pearson Education Limited.

24. Sewell, A. (2013). English as a lingua franca: Ontology and ideology. ELT Journal, 67 (1), 3-10.

25. Sánchez,M.,A.,A. (2000). An approach to the integration of skills in English teaching. Didáctica,Lenguay Literature. 12, 21-41.

26. Sbai, A.,M.(2016). Integrating or Segregating the Language Skills in EFL classroom? That's the Question. Retrieved fromhttps:// www.academia.edu/21732129/Integrating or_Segregating the_Language_Skills_in_EFL_classroom Thats_the_Question

27. Simon, M., K. (2011). Dissertation and scholarly research: Recipes for success. Seattle, WA: Dissertation Success, LLD.

28. Taqi,H \&Al-Nouh, N. (2014). Effect of Group Work on EFL Students' Attitudes and Learning in Higher Education. Journal of Education and Learning. 3,2.

29. Tavil,Z.,M.(2010). Integrating listening and speaking skills to facilitate English language learners' communicative competence. Procedia Social and Behavioral Sciences,9,765- 770 .

30. Tajan,M., H.(2016). Integrated listening activities on EFL learners' speaking fluency. International Journal of English Language Teaching.4(7),26-33.

31. Tajan, M., H, Sadeghi,B., \& Rahmany,R. (2015). The effect of integrated listening activities on EFL learners' speaking accuracy.International Journal of Language Learning and Applied Linguistics World. 9(4), 74-82. 


\section{Appendix A}

The table (4) below summarises the findings for the students' responses to the speaking items

Table 4

Descriptive Statistics for Speaking

\begin{tabular}{|c|c|c|c|c|c|c|c|c|}
\hline Item & & Always & Often & Sometimes & Rarely & Never & Mean & Std. \\
\hline \multirow{2}{*}{$\begin{array}{l}\text { 1. How often do you face } \\
\text { difficulty with speaking? }\end{array}$} & N. & 9 & 28 & 29 & 21 & 14 & \multirow[t]{2}{*}{3.03} & \multirow[t]{2}{*}{1.187} \\
\hline & $\%$ & 8.9 & 27.7 & 28.7 & 20.8 & 13.9 & & \\
\hline \multirow{2}{*}{$\begin{array}{l}\text { 2.How often do you have } \\
\text { difficulty participating in large } \\
\text { group discussions or in } \\
\text { debates? }\end{array}$} & N. & 11 & 23 & 31 & 22 & 14 & \multirow[t]{2}{*}{3.05} & \multirow[t]{2}{*}{1.203} \\
\hline & $\%$ & 10.9 & 22.8 & 30.7 & 21.8 & 13.9 & & \\
\hline \multirow[b]{2}{*}{$\begin{array}{l}\text { 3. Do you have interaction with } \\
\text { native speakers of English? If } \\
\text { yes, how often do you struggle } \\
\text { with interaction with native } \\
\text { speakers of English? }\end{array}$} & N. & 3 & 15 & 28 & 8 & & \multirow[t]{2}{*}{2.76} & \multirow[t]{2}{*}{.775} \\
\hline & $\%$ & 3.0 & 14.9 & 27.7 & 7.9 & & & \\
\hline \multirow{2}{*}{$\begin{array}{l}\text { 4. How often do you have } \\
\text { difficulty giving oral } \\
\text { presentations? }\end{array}$} & N. & 11 & 15 & 34 & 24 & 15 & \multirow[t]{2}{*}{3.17} & \multirow[t]{2}{*}{1.196} \\
\hline & $\%$ & 10.9 & 14.9 & 33.7 & 23.8 & 14.9 & & \\
\hline \multirow{2}{*}{$\begin{array}{l}\text { 5. How often do you have } \\
\text { trouble saying what you want } \\
\text { to say quickly enough? }\end{array}$} & N. & 15 & 21 & 40 & 17 & 8 & \multirow[t]{2}{*}{2.82} & \multirow[t]{2}{*}{1.126} \\
\hline & $\%$ & 14.9 & 20.8 & 39.6 & 16.8 & 7.9 & & \\
\hline \multirow{2}{*}{$\begin{array}{l}\text { 6. .How often do you worry } \\
\text { about making a mistake in } \\
\text { speaking? }\end{array}$} & N. & 16 & 29 & 24 & 16 & 16 & \multirow[t]{2}{*}{2.87} & \multirow[t]{2}{*}{1.309} \\
\hline & $\%$ & 15.8 & 28.7 & 23.8 & 15.8 & 15.8 & & \\
\hline \multirow{2}{*}{$\begin{array}{l}\text { 7. How often do you have } \\
\text { difficulty with your } \\
\text { pronunciation of words? }\end{array}$} & N. & 10 & 16 & 38 & 26 & 11 & \multirow[t]{2}{*}{3.12} & \multirow[t]{2}{*}{1.116} \\
\hline & $\%$ & 9.9 & 15.8 & 37.6 & 25.7 & 10.9 & & \\
\hline \multirow{2}{*}{$\begin{array}{l}\text { 8. How often do you practice } \\
\text { speaking skill outside the } \\
\text { classroom? }\end{array}$} & N. & 25 & 23 & 30 & 16 & 7 & \multirow[t]{2}{*}{2.57} & \multirow[t]{2}{*}{1.219} \\
\hline & $\%$ & 24.8 & 22.8 & 29.7 & 15.8 & 6.9 & & \\
\hline
\end{tabular}




\section{Appendix B}

$2^{\text {nd }}$ year students' interview

Gender: College: Class: Date:

1. Is your listening and speaking class interesting? Why?

2. Do you enjoy your listening and speaking class? Why?

3. What difficulties do you face in your listening and speaking class?

4. Does your listening and speaking class help you to improve your speaking skill? Why.

5. If you could meet a native speaker of English in person, would you be able to have a conversation with her/him?

6. What do you suggest for your teacher to add to your listening and speaking class?

Note: The students' interview questions, except for (4, 5, and 6) are adapted from Richards, J.C. (2001). Curriculum development in language teaching. Cambridge University Press. 


\section{Appendix C}

\section{Questionnaire for second year students}

\begin{tabular}{|c|c|c|c|c|c|}
\hline Item & Always & Often & Sometimes & Rarely & Never \\
\hline 1. How often do you face difficulty with speaking? & & & & & \\
\hline $\begin{array}{l}\text { 2.How often do you have difficulty participating in large group } \\
\text { discussions or in debates? }\end{array}$ & & & & & \\
\hline $\begin{array}{l}\text { 3. Do you have interaction with native speakers of English? If ye } \\
\text { how often do you struggle with interaction with native speakers } \\
\text { English? }\end{array}$ & & & & & \\
\hline 4. How often do you have difficulty giving oral presentations? & & & & & \\
\hline $\begin{array}{l}\text { 5. How often do you have trouble saying what you want to say } \\
\text { quickly enough? }\end{array}$ & & & & & \\
\hline 6. .How often do you worry about making a mistake in speaking & & & & & \\
\hline $\begin{array}{l}\text { 7. How often do you have difficulty with your pronunciation of } \\
\text { words? }\end{array}$ & & & & & \\
\hline $\begin{array}{l}\text { 8.How often do you practise your speaking skill outside the } \\
\text { classroom? }\end{array}$ & & & & & \\
\hline
\end{tabular}

Note: The questionnaire is adapted from Richards, J.C. (2001). Curriculum development in language teaching.

Cambridge University Press. 


\section{Appendix D}

\section{Consent form}

Project Title (MA Thesis): An Investigation and Evaluation of the Integrated Language Skills Approach at English Departments at UOD: Speaking

Name of Researcher: Sabrin Ali

Email: Sabreendoski@gmail.com

Please read the following statements:

1. I confirm that I have read and understood the information sheet for the above study. I have had the opportunity to consider the information, ask questions and have had these answered satisfactorily.

2. I understand that my participation is voluntary and that I am free to withdraw at any time without giving a reason.

3. I understand that any information given by me may be used in future reports, academic/professional articles, publications or presentations by the researcher/s, but my personal information will not be included and I will not be identifiable.

4. I agree to take part in the above study.

Date: $\quad$ Signature:

I confirm that the participant was given an opportunity to ask questions about the study, and all the questions asked by the participant have been answered correctly and to the best of my ability. I confirm that the individual has not been coerced into giving consent, and the consent has been given freely and voluntarily.

Signature of Researcher / person taking the consent

Date

Note: The consent form is adapted from

https://www.research-integrity.admin.cam.ac.uk/research-ethics/ethics-application-guidance/consent- 
forms-and-participant-information-sheets.

\section{Appendix E}

Dear Sir/Madam,

My name is Sabrin Ali Ramadhan. I am an MA/TESOL candidate at the College of Languages at UOD. I am currently conducting my MA research on the topic "An Investigation and Evaluation of the Integrated Language Skills Approach at English Departments at UOD: Speaking". It would be an asset for the work if you contribute with your comments and judgement as jury members, on the different parts of the questionnaire, and interview questions that I will be adopting in carrying out my experimental part.

Through the questionnaires, and interviews, I am trying to test my research hypothesis, stated below:

1.The integration of listening and speaking skills improves learners' speaking ability.

Your time and contribution are very much appreciated.

The researcher

Sabrin Ali Ramadhan 


\section{Appendix F}

Jury members' names

The specialists are:

1. Prof. Alya M.H. Ahmed. Ph. D.

College of Languages, University of Duhok.

2. Prof. Himdad A. Muhammad. Ph. D.

Knowledge University- Erbil

3. Assist prof. Lazgin Barany.

College of Languages, University of Duhok.

4. Dr. Asma' Bamerni. Ph. D.

College of Languages, University of Duhok.

5. Dr. Saeed Idress. Ph. D.

College of Basic Education, University of Duhok.

6. Dr. Haveen Mohammed Abdulmajeed. Ph. D.

College of Languages, University of Duhok. 